\title{
Pemberdayaan masyarakat melalui penataan dan pembinaan organisasi PKK dalam memanfaatkan limbah sawit di Kampung Sialang Palas, Riau
}

\author{
Khairul Anwar*, Syafri Harto, Isril, Adiwirman, \& Wan Asrida \\ Universitas Riau \\ * khairulanwar147@yahoo.com
}

\begin{abstract}
Abstrak. Kegiatan pengabdian kepada masyarakat ini bertujuan meningkatkan pengetahuan dan keterampilan organisasi PKK dalam mengelola kelompok dan mengolah limbah sawit dan ternak. Kegiatan ini dilatar belakangi oleh kondisi Kampung Sialang Palas, Kabupaten Siak tahun 2001 sebagai wilayah tumbuh cepat di provinsi Riaus. Daerah ini menjadi salah satu sasaran utama penerapan kebijakan pembangunan perkebunan kelapa sawit yang paling intensif dan ekstensif di Riau. Namun pola pemanfatan lahan dan limbah sawit belum optimal. Kondisi ini berimplikasi kepada pola pendapatan rumah tangga masyarakat. Muncul pertanyaan bagaimana limbah dapat dimanfaatkan? Untuk menjawap pertanyaan tersebut dilakukan kegiatan pelatihan dan penyuluhan dengan metode pelatihan dan penyuluhan model open governance danTeknologi Tepat Guna (TTG) Kegiatan dilakukan secara beerkelompok dengan materi pengetahuan kepemimpinan, manajemen dan teknolopengelolaan limbah sawot dan ternak. Hasil kegiatan pengabdian berupa: Pertama, pengetahuan dan keterampilan mengelola kelompok. Kedua, keterampilan mengolah limbah sawit dan ternak sapi menjadi piring, tikar, briket dan pupuk. Produk pengelohan limbah ini diharapkan menjadi alternative pendapatan rumah tangga masyarakat dan petani sawit swadaya terutama dalam masa peremajaan kelapa sawit (replanting).
\end{abstract}

Kata kunci: pemberdayaan; PKK; manajemen; pemanfatan limbah

\begin{abstract}
This community service activity aims to increase the knowledge and skills of the PKK organization in managing groups and treating palm and livestock waste. This activity was motivated by the condition of Sialang Palas Village, Siak Regency in 2001 as a fast growing area in Riaus province. This area is one of the main targets of implementing the most intensive and extensive oil palm plantation development policy in Riau. But land use and palm oil waste patterns are not optimal. This condition has implications for community household income patterns. The question arises how can waste be utilized? To answer this question, training and counseling activities are carried out using training methods and counseling on open governance models and Appropriate Technology (TTG). Activities are conducted in groups with leadership, management and technology knowledge of sawot and livestock waste management. The results of the community service activities are: First, the knowledge and skills to manage the group. Second, the skills to process palm oil and cattle waste into plates, mats, briquettes and fertilizers. This waste declining product is expected to be an alternative household income for the community and independent smallholders, especially during the rejuvenation of oil palm (replanting).
\end{abstract}

Keywords: empowerment; PKK; management; waste utility

To cite this article: Anwar, K., S. Harto, Isril, Adiwirman, \& W. Asrida. 2019. Pemberdayaan masyarakat melalui penataan dan pembinaan organisasi PKK dalam memanfaatkan limbah sawit di Kampung Sialang Palas, Riau. Unri Conference Series: Community Engagement 1: 442-448 https://doi.org/10.31258/unricsce.1.442-448

(C) 2019 Authors

Peer-review under responsibility of the organizing committee of Seminar Nasional Pemberdayaan Masyarakat 2019 


\section{PENDAHULUAN}

Kegiatan pengabdian masyarakat ini adalah bentuk kegiatan lanjutan dari program pengabdian tahun 2017 di Kabupaten Siak. Program kegiatan ini merupakan hasil penelitian Prioritas Nasional Masterplan Percepatan Dan Perluasan Pembangunan Ekonomi Indonesia (MP3EI) 2011-2025 dan dilanjutkan Penelitian Strategis Nasional Intsitusi (PSN) 2018. Dalam tahun 2018, hasil-hasil penelitian ini diaplikasikan kepada masyarakat kampung Sialang Palas Kecamatan Lubuk Dalam Kabupaten Siak. Kegiatan pengabdian ini tetap bertolak dari upaya nyata memanfaatkan potensi limbah sawit dan ternak sapi yang ada di Kabupaten Siak sesuai dengan kebijakan Pemerintah Kabupaten Siak terkait "One Village One Product".

Kebijakan ini adalah kebijakan yang bertujuan meningkatkan daya saing masyarakat dan petani di Riau. Daerah Riau adalah wilayah yang memiliki perkebunan kelapa sawit terluas di Indonesia. Daerah ini memiliki luas lahan perkebunan kelapa sawit tahun 2017adalah seluas 2,7 juta hingga 4,7 juta ha. Dalam kondisi seperti ini, muncul wacana Pemerintah untuk memenuhi $90 \%$ pangan asal ternak melalui program Sistem Integrasi Kelapa Sawit-Sapi (SISKA) dan program peremajaan kebun kelapa sawit (replanting) (Syahza et al., 2018). Berbagai program ini merupakan tantangan sekaligus peluang bagi masyarakat desa terutama petani swadaya.

Sejak di terapkannya kebijakan desentralisasi dan Otonomi Daerah (OTDA) Daerah Kabupaten Siak sebagai wilayah tumbuh cepat. Daerah ini menjadi salah satu sasaran utama penerapan kebijakan pembangunan perkebunan kelapa sawit yang paling intensif dan ekstensif di Riau. Daerah ini memiliki luas wilayah daratan 8.556,09 $\mathrm{km}^{2}$ dengan jumlah penduduk tahun 2015388.506 jiwa yang terdiri dari 203.394 jiwa penduduk laki-laki dan 185.112 jiwa penduduk perempuan dengan tingkat kepadatan penduduk sebesar 45 jiwa per $\mathrm{km}^{2}$. Kabupaten Siak memiliki 14 Kecamatan dan kampung. Secara umum mata pencaharian masyarakat di kabupaten ini umumnya terdiri dari sektor pertanian perkebunan dan peternakan. Namun sejak kebijakan desentralisasi dan otonomi daerah (OTDA) dilaksanakan, lahan sawah mengalami penurunan sebesar 1.047 ha dari tahun 2008 ke tahun 2009. Diikuti luas hutan rakyat semakin merosot dari 50.191 ha pada tahun 2008 menjadi 28.626 ha pada tahun 2009 (berkurang seluas 21.565 ha dalam setahun). Kondisi ini berimplikasi kepada pola pemanfaatan lahan di kecamatan Lubuk Dalam termasuk kampung Sialang. Sementara itu, Hutan negara berkurang dari 311.947 ha pada tahun 2008 menjadi 179.379 ha pada tahun 2009 (berkurang seluas132.568 ha dalam setahun). Penambahan terjadi padaluas perkebunan dari176.189 ha pada tahun 2008 menjadi 199.278 ha pada tahun 2009 (penambahan sebesar 23.089 ha dalam setahun). Pengalihan fungsi lahan yang terjadi secara drastis membawa dampak yang signifikan terhadap lingkungan dan tata kelompok masyarakat di Kabupaten Siak.

Kecamatan Lubuk Dalam adalah salah satu Kecamatan hasil pemekaran di wilayah Kabupaten Siak.Kecamatan ini dijadikan tempat pelaksanaaan pengabdian kepada masyarakat karena wilayah ini berada dalam kawasan yang terhitung dinamik dan menjadi wilayah sentra perkebunan utama di kabupaten Siak. Kampung Sialang Palas adalah kampung pertanian dan perkebunan kelapa sawit yang dekat pusat pemerintahan ibu kota Siak Sri Indrapura dan Ibu Kota Provinsi Riau Pekanbaru. Daerah ini menjadi pintu masuk Riau pesisir dan daratan. Masyarakat kampung umumnya bermata pencaharian pertanian, perkebunan, dan peternakan. Masyarakat kampung umumnya berasal dari warga transmigrasi di Kabupaten Siak.

Dalam kondisi ini, muncul kebutuhan untuk meningkatkan kapasitas organisasi PKK melalui kegiatan pengabdian kepada masyarakat. Kegiatan pengabdian kepada masyarakat ini bertujuan: (1) meningkatkan kapasitas organisasi PKK dalam mengelola limbah sawit dan ternak melalui aplikasi model "open governance" (2) Meningkatkan ekonomi rumah tangga petani melalui pemanfaatan potensi SDA unggulan kampung dalam rangka meningkatkan daya saing daerah yang unggul.

Kegiatan pengabdian ini mengambil bentuk pada pelatihan pengembangan manajemen organisasi dan TTG aplikasi model "open governance". Model ini dirancang untuk menuntun pemberdayaan PKK melalui penataan kelembagaan dalam memanfaatkan SDA. Berdasakan identifikasi makro situasi yang telah disampaikan, permasalahan yang akan dicarikan solusinya adalah sebagai berikut: (1) Bagaimana meningkatkan pengetahuan dan keterampilan organisasi PKK? (2) Bagaimana cara menggerakkan potensi organisasi dalam mengolah limbah sawit dan ternak melalui model open governace? Dalam rangka menjawab pertanyaan tersebut, kegiatan pengebdian ini dituntun oleh konsep teori interest-group politics.

\section{METODE PENERAPAN}

Dalam rangka mencapai tujuan kegiatan pengabdian kepada masyarakat ini, metode yang dipakai adalah: Pertama, ceramah dan diskusi. Tujuan dilakukan ceramah dan diskusi ini adalah: (1) untuk menjelaskan model "open governance" dalam kaitan kebijakan "one village one product" dan sekaligus menjaring aspirasi 
masyarakat kampung kepada khalayak sasaran; (2), untuk mengidentifikasi potensi SDA dan kepentingan masyarakat yang berkembang secara lebih lengkap, dan; (3), untuk menggali pemahaman tentang bagaimana perangkat kampung dan masyarakat memanfaatkan limbah sawit bagi pemingkatan rumah tangga. Sebelum diskusi terlebih dahulu disusun peta isu SDA di Kampung Sialang Palas.

Adapun materi kegiatan ceramah dan diskusi ini terdiri dari penjelasan dan contoh-contoh isu-isu strategis pembangunan yang berdampak terhadap pembangunan baik tingkat lokal (Deliana \& Rasudin, 2019), regional, dan global; pentingnya memahami masalah dari berbagai isu strategis yang terjadi di desa; mengkaitkan unsure-unsur model pemerintahan terbuka dengan isu-isu pembangunan pedesaan; menjelaskan manfaat model kedalam metode pengumpulan data (wawancara, observasi, dokumentasi, FGD, dll). Ceramah dan diskusi dilakukan menggunakan alat bantu slide, proyektor, komputer dan alat-alat tulis. Kedua, Simulasi kegiatan memanfaatkan limbah kelapa sawit. Metode ini dilakukan dengan cara mendemontrasikan praktik megolah limbah sawit menjadi kerangjnag, piring dan tikar. Kegiatan ini melibatkan mahasiswa KUKERTA UNRI di dua kampung yaitu Sialang Palas dan Empang Baru. Secara umum kegiatan ini membagi khalayak sasaran kedalam dua kelompok. Masing-masing kelompok akan disampaikan ilustrasi kasus pembangunan dan masing kelompok akan merumuskan tema, menenukan informan, jenis aspirasi, metode yang digunakan dalam menemukan kebutuhan masyarakat dan membuat kesimpulan. Ketiga, evaluasi. Setelah kegiatan pengabdian berjalan, dilakukan evaluasi dengan tujuan ingin mengetahui dan menganalisis permasalahan yang muncul antara upaya pencapaian tujuan yang sudah dirumuskan dan kenyataan praktik kegiatan yang berlangsung. Kesenjangan yang dijumpai akan menjadi permasalahan kegiatan pengabdian masyarakat yang akan dicari pemecahannya pada tahun berikutnya.

Indikator keberhasilan kegiatan pengabdian kepada masyarakat ini bertumpu kepada: (1) kehadiran khalayak sasaran dalam setiap tahapan kegiatan; (2) jumlah khalayak sasaran yang menginginkan kembali kegiatan ini kembali dilaksanakan; (3) pengetahuan dan keterampilan dalam memanfaatkan limbah sawit.

Adapun yang menjadi kelompok sasaran kegiatan adalah organisasi PKK di kampung Silalang Palas, Kecamatan Lubuk Dalam Kabupaten Siak. Kegiatan ini diharapkan bermanfaat bagi anggota organisasi PKK dalam bentuk mendapatkan tambahan pengetahuan dan keterampilan memenfaatkan limbah SDA dalam pembangunan yang partisipatif.

\section{HASIL DAN SASARAN}

\section{Gambaran Umum Masyarakat Sasaran}

Dari data pra survey awal, kampung Sialang Palas adalah kampung dengan luas sekitar 1.660 Ha terdiri dari dua dusun, 4 Rukun Warga (RW) dan 15 Rukun tetangga (RT).Wilayah kampung ini terdiri dari daratan dengan kondisi geografis berbukit-bukit. Kampung Sialang Palas merupakan wilayah sebahagian penduduknya bermata pencaharian dari sektor pertanian dan perkebunan kelapa sawit disamping sektor peternakan dan sektor perikanan darat dan perdagangan.Kampung Sialang Palas memiliki jumlah penduduk 2.074jiwa, yang terdiri dari laki-laki 1.062 jiwa, perempuan 1.012 jiwa dan 600 Kepala Keluarga (KK). Tingkat pendidikan masyarakat kampung Sialang Baru sebagian besar tamat SD/sederajat (757 0rang), tidak tamat SD/Sederajat (480 orang), SLTP/Sederajat (355 orang), tamat D1 (8 orang), Tamat D3 (12 orang), dan S1 (22 orang) (Monografi Sialang Palas, 2015).

Potensi Kampung Sialang Palas terdiri dari sumberdaya alam terbesar yaitu perkebunan kelapa sawit (1.132,5 ha), dan pasir (3000 kubik). Sumberdaya sosial dan budaya misalnya kelompok-kelompok sosial keagamaan (majelis taklim, wirid yasin, lembaga adat, tokoh adat, rebana, kelompok kuda lumping).

\section{Potensi Pengembangan Masyarakat}

Seperti yang dikemukakan sebelumnya, tujuan pengabdian kepada masyarakat ini adalah Pertama; meningkatkan pengetahuan dan keterampilan organisasi PKK melalui peneraan model "open governance" dalam menjaring memanfaatkan limbah sawit dan ternak. Kedua, meningkatkan kemampuan manajemen organisasi PKK dalam mengelola, merespon dan mengkomunikasikan isu-isu dan masalah strategis ke dalam lembaga pemerintahan kampung dan masyarakat umumnya (Nik Abdullah, 2019). Tujuan kegiatan ini selaras dengan potensi masyarakat Kampung Sialang Palas khususnya dan Kecamatan Lubuk Dalam pada umumnya yaitu SDA perkebunan kelapa sawit, perikanan darat dan lembaga-lembaga sosial kemasyarakatan. Sementara potensi SDA tersebut belum terkapitalisasi sedemikian rupa dalam pembangunan Kampung Sialang Palas. Hal ini secara faktual nampak dari keterlibatan organisasi PKK dalam pembangunan kampung dan kapasitas 
lembaga-lembaga ekonomi dalam menggali sumber pendapatan kampung yang berasal dari potensi SDA perkebunan kelapa sawit, peternakan dan perikanan darat.

\section{Solusi Akan Dilaksanakan}

Solusi yang ditawarkan dalam mengatasi masalah pemberdayaan masyarakat Kampung Sialang Palas adalah menata kelembagaan dan pemberdayaan masyarakat kampung PKK dengan melakukan pendidikan politik melalui kegiatan ceramah dan pelatihan. Kegiatan pengabdian ini terdiri dari penjelasan dari contoh-contoh isu-isu strategis pembangunan misalnya isu pasar input. Isu ini terdiri dari materi sarana produksi pertanian (SAPROTAN). Isu pasar output misalnya pemasaran produksi pertanian dan perkebunan dan isu strategis pasar konsumsi petani misalnya upaya pemenuhan bahan-bahan konsumsi petani misalnya beras, kopi, gula, minyak goreng, air bersih, potensi lokal dan sebagainya (Julianti et al., 2018; Kustyawati et al., 2019). Berbagai isu strategis ini diduskusikan dan mengkaitkan dengan unsure-unsur model open governance menjelaskan manfaat model kedalam metode pengumpulan data misalnya wawancara, observasi, dokumentasi, FGD. Ceramah dan diskusi dilakukan menggunakan alat bantu slide, infokus, komputer, kamera dan alat-alat tulis. Selanjutnya untuk mempertajam kegiatan diskusi dilakukanlah metode simulasi mengolah limbah sawit dan ternak memalui TTG. Metode ini dilakukan dengan cara membentuk kelompok-kelompok kecil. Secara umum kegiatan ini membagi khalayak sasaran kedalam dua kelompok yaitu kelompok yang mengolah limbah kelapa sawit dan kelompok mengolah limbah ternak. Masing-masing kelompok akan disampaikan ilustrasi kasus pembangunan dan masing kelompok akan merumuskan tema, menenukan informan, jenis aspirasi, metode yang digunakan dalam menemukan kebutuhan masyarakat dan membuat kesimpulan.

Dalam mengakhiri kegiatan pengabdian ini di lakukan evaluasi. Setelah kegiatan pengabdian berjalan, dilakukan evaluasi dengan tujuan ingin mengetahui dan menganalisis permasalahan yang muncul antara upaya pencapaian tujuan yang sudah dirumuskan dan kenyataan praktik kegiatan yang berlangsung. Kesenjangan yang dijumpai akan menjadi permasalahan kegiatan pengabdian masyarakat yang akan dicari pemecahannya pada tahun berikutnya.

\section{Pelaksanaan Ceramah dan Diskusi}

Dalam mengorganisir laporan pelaksanaan kegiatan berikut ini akan diuraikan beberapa kondisi pelaksanaan kegiatan yang berjalan adalah sebagai berikut:

Kegiatan ceramah dimulai setelah disampaikan pengantar diskusi oleh pak penghulu kampung Sialang Palas Kecamatan Lubuk Dalam Kabupaten Siak. Dalam kata pengantarnya, Pak Penghulu berharap acara kegiatan pengabdian ini dapat meberikan manfaat kepada organisasi PKK yang hadir dan dapat diaplikasikan dalam meningkatkan pengetahuan dan keterampilan terutama ibu-ibu PKK. Kegiatan ceramah dan diskusi ini diikuti oleh 28 orang peserta yang terdiri dari 14 orang pria dan 14 orang wanita dihadiri oleh Kepala kampung Sialang Palas dan Mahasiswa KUKERTA UNRI 2019 bedrasal kampung Sialang palas dan Empang Baru dan tokoh-tokoh masyarakat.

Kegiatan dimulai pukul 13.30 WIB berakhir pukul 16.30 WIB bertempat di Gedung Balai Kampung Sialang Palas pada tanggal 9 Agustus 2019.

MATERI I : Penjelasan pengertian kaitan TriDharma Perguruan Tinggi, Penelitian dan Pengabdian kepada Masyarakat

MATERI II : Penjelasan apa yang dimaksud model "open governance"? Bagaimana latar belakangnya? Apa pentingnya dalam penyelenggaraan pemerintahan dan pembangunan kampung? Apa saja unsure-unsurnya? dan apa kelebihan atau manfaatkan dan apa saja keterbasatannya?

MATERI III : Demontrasi pembuatan tikar, piring dari limbah kepala sawit. Kegiatan ini dilakukan oleh dosen pembimbing dan mahasiwa KUKERTA UNRI 2019. Setelah itu, dilakukan Tanya jawab.

Seperti yang terjadi dewasa ini di Indonesia, demikian dalam masyarakat politik Riau, sejarah perpolitikan elit umumnya diwarnai pergulatan kepentingan terutama yang berkaitan sumber daya alam (SDA) lokal. Riau yang kaya SDA tetapi hasilnya lebih banyak dimanfaatkan oleh Pusat. Kondisi ini membuat masyarakat 
kecewa. Kekecewaan itu memuncak kembali masa diterapkannya kebijakan otonomi daerah (OTDA) dan puncaknya ketika dirumuskan dan diterapkannya kebijakan kelapa sawit.

Sejak tingkat wacana, kebijakan perkebunan sudah menimbulkan perdebatan panjang di Riau. Pergulatan tidak hanya terjadi antara pemerintah dan aktor non-pemerintah, akan tetapi friksi juga terjadi dengan aktor internasional. misalnya perusahaan multi nasinal (MNC). Aktor ini berkepentingan atas prospek pasar tingkat domistik dan dunia seperti yang dikampanyekan Pemerintah Pusat. kebutuhan akan biofuel yang semakin tinggi. Selain itu, dukungan terhadap kebijakan Sawit terus bertambah. Sebelum OTDA yang melakukan aksi terbatas hanya Anggota Dewan Perwakilan Rakyat Daerah (DPRD) dan Birokrasi Daerah. Setelah OTDA, aktor lokal yang melakukan aksi semakin beragam. Tokoh-tokoh yang semula tidak bisa mengungkapkan pendiriannya berubah menajadi sangat vokal. Hal ini ditandai dengan munculnya sejumlah aktor dari kelompok-kelompok (LSM) Lembaga Swadaya Masyarakat, gerakan massa, dan kelompok lainnya seperti Riau Merdeka.

MATERI IV : Penjelasan kaitan model dengan masalah-masalah pembangunan dan pemerintahan kampung Sialang Palas Kecamatan Lubuk Dalam umumnya. Bagaimana metodenya? Apa saja yang dilakukan? Bagaimana menggunakan alat-alat peraga model?

Model "open governance" ini terdiri dari dua tahap; pertama, kerangka dasar yang terdiri dari isi isu kebijakan, masalah, formulasi dan legitimasi kebijakan. Pada tingkat isi isu kebijakan keterlibatan kelompok PMS sudah intens dilakukan. Semakin beragam kelompok sosial yang ikut semakin terbuka kemungkinan perubahan akan kesadaran pentingnya pengelolaan konflik. Secara empirik, pada tingkat isi isu kebijakan ini meskipun beragam nilai yang ditawarkan namun seringkali didapatkan konsensus. Pada batas-batas tertentu memang dibutuhkan kemampuan menanamkan pengaruh dan setiap kelompok masyarakat biasanya ada yang berpengaruh. Tahapan ini menentukan tahapan masalah kebijakan, isu kebijakan dapat sama namun masalah yang dimunculkan sangat beragam. Hal ini sangat tergantung sudut pandang yang dipakai. Singkat kata, isu dapat sama namun masalahnya dapat berbeda. Secara empirik, inilah sumber konflik sosial-politik yang utama dewasa ini di tingkat lokal. Model-model kebijakan publik yang ada selama ini paling tidak untuk perkebunan kelapa sawit, kelompok PMS dilibatkan ketika baru muncul masalah. Oleh karena itu, model ini melibatkan PMS sejak tahapan isu kebijakan, masalah kebijakan, dan formulasi kebijakan. Sehingga tindakan pemerintah mendapat legitimasi.

Kedua, model ini mengetengahkan empat variabel ekonomi-politik utama yang seringkali menimbulkan ketegangan sosial-politik variabel tersebut adalah:

(1) aktor, mengidentifikasi pola dan arah interaksi aktor-aktor yang "mendukung" atau yang "menolak" dalam wacana dan pembangunan perkebunan kelapa sawit di Riau, dan menentukan apa yang menjadi tujuan dan kepentingannya. Langkah ini mengasumsikan para aktor adalah individu atau institusi yang berupaya memaksimalkan utulitas, dan melakukan perhitungan keuntungan dan kerugian sebaik-baiknya dalam mencapai tujuan. Selain itu akan dianalisis juga perilaku aktor dari kalangan Perusahaan pengembang kebun sawit.

(2) menggambarkan proses preferensi masing-masing aktor mengenai kebijakan perkebunan kelapa sawit yang akan diterapkan di Riau. Sebagaimana diketahui bahwa terdapat setidaknya empat pola kebijakan pengembangan kelapa sawit yakni Pola Perkebunan Besar Swasta, Perkebunan Besar Negara, Perkebunan Rakyat,Perusahaan Inti Rakyat (PIR),dan perkebunan K2I. Dari lima pola tersebut dalam pelaksanaannya terdapat paling tidak empat isu utama yang terkait dengan kebijakan perkebunan, yaitu; pertanahan, lapangan kerja, teknologi, dan lingkungan. Dalam menentukan pilihan-pilihan terhadap penanganan isu-isu ini para aktor digambarkan sebagai pihak yang suka pada pola yang dapat memaksimalkan keuntungannya.

(3) mendiskripsikan bagaimana para aktor berkoalisi dalam mencapai tujuan. Koalisi ini dilakukan dalam rangka memperkuat daya tawar terhadap kelompok lain. Para aktor mengkrompomikan kepentingannya dengan aktor atau kelompok lainnya. Langkah ini antara lain bertujuan untuk mendapatkan dukungan dalam memperkuat koalisi. Dalam kasus pembangunan kelapa sawit di Riau. Kelompok yang "mendukung" perolehan "hasil" kelapa sawit baik yang berasal dari kalangan pemerintah Daerah maupun swasta melakukan 
konsolidasi. Tujuannya agar dapat meyakinkan pihak yang menolak "rejeki" pembangunan kelapa sawit pada akhirnya dapat menerima.

(4) menganalisis faktor-faktor yang mempengaruhi para aktor berinteraksi dengan lembaga-lembaga sosial lainnya dalam rangka memperjuangkan kepentingan untuk mencapai tujuan. Apakah memakai pendekatan "bergaining", "persuasi", atau "komando", Aktor yang responnya "mendukung" pembangunan perkebunan kelapa sawit baik dari Pemerintah Daerah maupun Swasta mempunyai sumber daya ekonomi-politik besar berkemungkinan melakukan tawar menawar atau "tekanan" kepada aktor atau kelompok yang responnya "menolak" kebijakan atau "hasil" perkebunan kelapa sawit yang diperoleh masyarakat Riau.

MATERIV : Pelatihan memanfaat limbah sawit. Penyuluhan dan latihan ini dilakukan tim kegiatan pengabdian bersama mahasiswa Kuliah Kerja Nyata (KUKERTA).

Pemanfaatan limbah sawit dan ternak dalam buku ini dengan mengambil contoh kampung Sialang Palas di Kabupaten Siak. Sialang Palas merupakan salah satu Kampung di Kecamatan Lubuk Dalam, Kabupaten Siak, Provinsi Riau. Kampung ini memiliki luas wilayah 1.660 Ha yang sebahagian besar dimanfaatkan untuk usaha perkebunan kelapa sawit.

MATERI VI : Mendiskusikan materi I, II, III, IV, dan V dalam bentuk tanya jawab antara pelaku kegiatan pengabdian dengan peserta dan antara peserta dengan peserta lainnya.

Tanya jawab ini lebih banyak mengetengahkan sisi pengalaman masing-masing peserta dan bagaimana menggunakan model dalam penerapan kegiatan pemerintahan sehari-hari. Beberapa contoh pertanyaan dan jawabandalam diskusi sebagai berikut:

1) Apa "Open Governance" itu?

2) Bagaimana caranya mengolah limbah sawit dan ternak menjadi produk-produk agar dapat meningkatkan pendapatan rumah tangga petani?

3) Bagaaimana membuat produk dari limbah sawit \& ternak sapi?

4) Apa yang dimaksud dengan manajemen?

5) Bagaimana mengelola konflik sosial?

\section{KESIMPULAN}

Kegiatan pemberdayaan organisasi PKK di Kampung Sialang Palas, Kecamanatn Lubuk dalam Kabupaten Siak berimplikasi kepada persepsi diri anggota organisasi PKK dan pola pendapatan rumah tangga petani. Kegiatan pelatihan dan penyuluhan dengan metode pelatihan dan penyuluhan model open governance danTeknologi Tepat Guna (TTG) Hasil kegiatan pengabdian berupa: Pertama, pengetahuan dan keterampilan mengelola kelompok. Kedua, keterampilan mengolah limbah sawit dan ternak sapi menjadi piring, tikar, briket dan pupuk. Produk pengelohan limbah ini diharapkan menjadi alternative pendapatan rumah tangga masyarakat dan petani sawit swadaya terutama dalam masa peremajaan kelapa sawit.

Dalam konteks pemberdayaan organisasi PKK di Kampung Siaqlang Palas, Kecamatan lubuk Dalam dipandang penting melibatkan semua pihak stakeholders. Program-program pemberdayaan masyarakat desa yang dibuat Pemda sebaiknya diarahkan kepada usaha pendampingan kelompok-kelompok PKK secara berkelanjutan sesuai dengan potensi modal sosial organisasi PKK. Kepada para pelaku bisnis diharapkan bersinergi dengan Pemerintah Kampung daan Perguruan Tinggi dalamk membangun kemitraan dalam mengembangkan organisasi PKK untuk memanfaatkan SDA terutama kelapa sawit dan ternak yang menghasilkan produk-produk unggulan lokal ke depan.

\section{DAFTAR PUSTAKA}

Anwar, K. 2014. Synergistic environment policy formulation model: Palm oil case K2I in Riau. Indonesian Journal of Environment Science and Technology 1(1).

Anwar, K, et al. 2015. Political Model of Conflic Based on palm Plantation near to Riverside area: Dosan Siak case, 2009-2014 dalam prosiding. Seminar Antar bangsa ke-8 Ekologi manusia dan Perubahan Persekitaran, Langkawi, Kedah Malaysia, 21-22 September 2015. 
Anwar, K. 2014. Sinergi dan Strategi Kebijakan Desentralisasi Lintas Kementerian: Studi Kasus Kebijakan Kelapa Sawit K2-I di Riau. DP2M Dikti. Jakarta.

Anwar, K. 2013. Pemetaan dan Strategi Kebijakan Pengelolaan Kelapa Sawit DAS Siak 2005-2010.

Anwar, K. 2012. Formulasi Kebijakan di Bidang Kelapa Sawit. Jurnal JIANA 4(5).

Syahza, A., D. Bakce, \& B. Asmit. 2018. Increasing the awareness of palm oil plantation replanting through farmers training. Riau Journal of Empowerment 1(1), 1-9. https://doi.org/10.31258/raje.1.1.1

Deliana, E., \& N. Rasudin. 2019. Legal Review of Local Wisdom of Indigenous Communities of Siak District in the Management of Slum Housing and Slum Settlement Locations. Indonesian Journal of Economics, Social, and Humanities 1(1): 25-36. https://doi.org/10.31258/ijesh.1.1.3

Julianti, E., Ridwansyah, T. Karo-Karo, \& Halimatuddahliana. 2018. Diversifikasi produk melalui pemanfaatan tepung umbi-umbian lokal sebagai pengganti terigu pada UKM bakery di Kota Binjai. Riau Journal of Empowerment 1(2): 75-83. https://doi.org/10.31258/raje.1.2.10

Kustyawati, M. E., R. Sugiharto, S. Waluyo, \& Erlina. 2019. Pemberdayaan wanita Kelompok Serba Usaha Srikandi melalui diversifikasi produk kopi bubuk herbal. Riau Journal of Empowerment 2(1): 15-20. https://doi.org/10.31258/raje.2.1.13

Nik Abdullah, N. A. 2019. Gaining competitive advantage through new product development capability in Malaysian Government Linked Companies. Indonesian Journal of Economics, Social, and Humanities 1(1): 37-49. https://doi.org/10.31258/ijesh.1.1.4

Syahyuti. 2012. Pengorganisasian Diri Petani Dalam Menjalankan Agribisnis di Pedesaan: Studi Lembaga dan Organisasi Petani dalam Pengaruh Negara dan Pasar. Disertasi. Fakultas Ilmu Sosial dan Ilmu Politik Program Pascasarjana Sosiologi Universitas Indonesia. 